\title{
Overweight Problem among Early Adolescents in Preparatory Schools in Tanta City
}

\author{
AYA M. RABIE, M.Sc.; WALAA M. SHEHATA, M.D.; NADIRA MANSOUR HASAN, M.D. and \\ NIHAL SALAH EL-DEEN SHIHAB, M.D.
}

The Department of Public Health and Community Medicine, Faculty of Medicine, Tanta University

\begin{abstract}
Background: Overweight is a major public health problem affecting adolescents. Prevalence of overweight and obesity is rapidly increasing. Good nutritional knowledge and behavior may help in prevention of overweight and obesity.

Aim of Study: 1- Assess the prevalence of overweight and obesity among preparatory school children in Tanta City. 2Assess students' nutritional knowledge and eating habits.

Subjects and Methods: Cross sectional study carried-out at the preparatory schools in Tanta City, Egypt. The study subjects included; 250 boy and 250 girl were chosen by stratified random sample technique. The first stratum was boys and girls schools and the second stratum was school grades. Each school was divided into three grades and one class was chosen randomly from each grade.

Tools of the Study:

1- Predesigned questionnaire asked about (sociodemographic data, nutritional knowledge and eating behavior).

2- Weight and height measurements to calculate BMI.

Results: The prevalence of overweight and obesity among studied group was $(22.8 \%$ and $11.8 \%)$ respectively. Prevalence of overweight among girls and boys $(13.4 \%$ and $9.4 \%)$ respectively, while obesity (5.2\% and $6.6 \%$ ) respectively. (76.4\%) of the students had fair nutritional knowledge level while only $(19.4 \%)$ of them had good nutritional knowledge. (88.4\%) of the students had fairly sound nutritional behavior while only $(5.4 \%)$ of them had sound nutritional behavior.

Conclusion and Recommendations: More than one fifth of the students in the study were overweight with smaller percent of obesity. Overweight was more common among females while obesity was more among males. Fair nutritional knowledge and behavior were found in most of the students. So we should encourage healthy eating among adolescents and provide healthy snacks at school canteen with a suitable price. Guide students and their families to the best YouTube channels that can help them to prepare healthy food in a rapid and delicious way.
\end{abstract}

Key Words: Overweight-Obesity-Adolescents - Nutritional knowledge - Nutritional behavior.

Correspondence to: Dr. Aya Mohamed Rabie Abd El-Ghaney, E-Mail: ayarabie89@yahoo.com

\section{Introduction}

NUTRITION is an essential component of total adolescence health care. Changes occurring during adolescence can cause a crisis in the nutritional needs. Eating habits may change from regular meals prepared at home to irregular meals, skipped meals, poor snacks and fast food meals. Healthy eating is associated with reduced risk for many diseases, including several of the leading causes of death: Heart disease, cancer, stroke, and diabetes [1].

Overweight and obesity have increased globally among children, adolescents, and adults. During adolescence, overweight and obesity are often a burden that results in psychosocial problems and a reduced capacity for physical activity. Adolescence is a critical period for the onset of obesity and for obesity-associated morbidity in later life. Therefore, from a public health perspective, it is important to monitor overweight in adolescence [2].

Several studies showed the prevalence of overweight and obesity. The Middle East and North Africa region has the highest rates of overweight and obesity of the developing world with implications for the global disease burden and local health service capacity. Egypt is the largest country in the region and has one of the highest levels of female obesity ( 46\%), exceeding the UK and USA [3]. In general, overweight was more prevalent than obesity in both males and females [4].

In Egypt data from several nationally representative surveys carried by National Nutrition Institute (NNI) and Egypt Demographic and Health Survey (EDHS) (2008) revealed that the overall prevalence of overweight and obesity among the age group (10-18 years old) ranged between 19 to $23 \%$ with 
higher prevalence rates among females (22.9 to $29.6 \%$ ) compared to males (14.7 to $20.7 \%)$ [5,6] .

Food intake has been related to obesity not only in terms of the volume of food ingested, but also in terms of the composition and quality of the diet. Furthermore, eating habits have also changed and current habits-including the low consumption of fruits, greens and milk, increasing consumption of cookies with fillings, salty industrialized snacks, sweets and soft drinks, as well as not having breakfast help explain the continuous increase in adiposity among children $[\mathbf{7 , 8}]$.

In order to promote healthier eating habits, and consequently, decrease the rates of obesity, knowledge about food and nutrition is believed to be important [9]. Studies that utilized nutritional education as an intervention strategy, have reported an improvement in nutritional knowledge, attitudes and eating habits, that also influenced the family's eating habits $[\mathbf{8 , 1 0}]$

So the purpose of this study is to assess the overweight and obesity problem among early adolescence, their nutritional knowledge, dietary behaviors and barriers to healthy eating as a primary step for future planning suitable intervention programs. Early adolescence starts with the onset of puberty which is one of the most rapid phases of physical growth and hormonal changes. Nutrition is an essential component of total adolescence health care. Changes occurring during adolescence can cause a crisis in the nutritional needs.

\section{Subjects and Methods}

It was a cross sectional study carried out at the preparatory schools in Tanta City, Egypt on early adolescents age from (12-15) years. This study started from the first of October 2017 and completed by December 2018.

Subjects in this study were chosen randomly from preparatory schools in Tanta City by disproportionate stratified random sample technique.

The first stratum in this sample: Were boys and girls schools.

Three schools for boys (2 governmental schools: Mohamed Farid school and Tanta preparatory school and 1 private school: Elgeel Elmoslem school) and three schools for girls (2 governmental school: El-Mensawy School and El-Sayda Eisha School and 1 private school: Noterdam School). The schools were chosen randomly (by a simple random technique) from both governmental and private schools in both administrations.

\section{The second stratum:}

One class was chosen randomly from each grade in each school. All the students in each chosen class were included in the study. The student number in each class is about 30 to 35 students in average.

So, finally the study included nine classes for boys and nine classes for girls to justify the sample size.

\section{Sample size calculation:}

The minimal sample size for this study was calculated by this equation:

$$
\mathrm{N}=\frac{(1.96)^{2} \mathrm{X} \mathrm{pq}}{\mathrm{D}^{2}}[11]
$$

Whereas 1.96 is the critical value of $\mathrm{z}$ at the adopted $95 \%$ confidence level which can be approximated to 2 providing that the population is normally distributed. The $p$ (proportion) is equal to the prevalence of overweight in the adolescence which is estimated to be $20 \%$ as an average from previous studies in Egypt [5,6]. D refers to the confidence interval around the estimate. The $\mathrm{d}$ or the precision should not exceeds $20 \%$ out of the proportion $p$.

$$
\mathrm{N}=\frac{(1.96)^{2} \mathrm{Xpq}}{\mathrm{d}^{2}}
$$

After approximation of $\mathrm{Z}$,

$$
\mathrm{N}=\begin{aligned}
& 4 \mathrm{XP}(1-\mathrm{P}) \\
& \mathrm{d}^{2}
\end{aligned}
$$

If $d=0.04$ (20\% out of the prevalence of $20 \%)$.

$$
\mathrm{N}=\frac{4 \times 0.20(1-0.20)}{0.042}
$$

$\mathrm{N}=400$ student (the minimal sample size $)+80$ (the estimated loss in Persons completing the study) $=480$.

So a sample of 500 students justified the study.

\section{Inclusion criteria:}

All students at the three preparatory grades of the selected schools were included.

\section{Exclusion criteria:}

Chronically ill children (diabetic, cardiac, asthmatic, epileptic children, any child treated with corticosteroids and other chronically ill children). 
Pretest study: It was carried out before starting data collection including $10 \%$ of the expected sample size (not included in the study) with the following objectives:

- To test and evaluate the adequacy of the designed questionnaire.

- To estimate the time needed for filling questionnaire sheet (it took about 20 minutes to be completed) and assessment of weight and height for each study subject.

- To determine the potential obstacles that might be met with during the execution of the study.

Tools of the study:

1- Tool (1) questionnaire: Formed of 3 parts:

- Sociodemographic data: Questions were asked to gather background information of the participants about: Age, sex, residence, educational grade, father education, father job, mother education, mother job and family history of obesity.

- Nutritional knowledge and eating behavior questions regarding healthy dietary habit [12] .

To assess the following:

* Students' nutritional knowledge:

- It contains 12 questions. The response categories were scored as 1 for correct answer, 0 for incorrect answer.

- The total score of them ranged from (0-12). If the total score was:

- Two thirds or more ( $\geq 66.7 \%)$ was considered as having good nutrition knowledge.

- One third to less than two third $(33.3 \%$ $<66.7 \%$ ) was considered as having fair nutritional knowledge.

- Less than one third $(<33.3 \%)$ was considered as having poor nutritional knowledge.

* Students 'nutrition behavior: Consists of 20 questions about eating habits.

- The total score of this section was 52. If the total score was:

- Two thirds or more $(\geq 66.7 \%)$ was considered sound nutritional behavior.

- One third to less than two third $(33.3 \%$ $<66.7 \%$ ) was considered fairly sound nutritional behavior.

- Less than one third $(<33.3 \%)$ was considered to have unsound nutritional behavior.

Barriers to healthy eating questionnaire [13] "Barriers" had nine questions that related to differ- ent potential barriers. Responses were measured on a nominal scale as yes, no.

2- Tool (2): Weight and height measurement to calculate BMI: BMI was estimated by dividing weight $(\mathrm{kg})$ by height ${ }^{2}\left(\mathrm{~m}^{2}\right)$. According to The Egyptian Growth Charts 2002 [14], BMI-forage.

Weight status categories and the corresponding percentiles are:

Table (I): Weight status categories and percentiles.

\begin{tabular}{ll}
\hline - Underweight & $\bullet$ Less than the 5 th percentile \\
- Normal or healthy & $-5 \mathrm{t}^{\mathrm{h}}$ percentile to less than the $85 \mathrm{t}^{\mathrm{h}}$ \\
weight & percentile \\
- Overweight & $-85 \mathrm{t}^{\mathrm{h}}$ to less than the $95 \mathrm{t}^{\mathrm{h}}$ percentile \\
- Obese & $-95 \mathrm{t}^{\mathrm{h}}$ percentile or greater \\
\hline
\end{tabular}

Validity and reliability:

Were assessed for tools used in this study through:

- Cronbach's Alpha test, its result was 0.8.

- Face and content validity.

\section{Ethical consideration:}

Ethical considerations of the study were carried out according to that of Ethical Committee for Research at Tanta Faculty of Medicine. Oral and written informed consent was obtained from parents of participant in the study groups, while those who refused to participate were not included. Data was not used for any purpose other than the scientific research.

\section{Statistical analysis of data:}

Statistical analysis was performed using SPSS Package 20 for Microsoft Windows. Numerical data were presented as mean and standard deviation and categorical ones as number and percentage.

\section{Results}

The sample included 500 students, $50 \%$ of them were males and $50 \%$ were females with their age ranges from 12 to 15 years old and the mean age was $13.03 \pm 0.961$. The entire sample was from urban areas. Percentage of studied participants was nearly the same from the three grades. More than half $(52 \%)$ of the participants' fathers completed university education and about one third (36\%) of them were employee. On the other hand, more than one third $(38.4 \%)$ of the participants' mothers completed university education and more than half $(60.6 \%)$ of them were housewives (Table 1). Prev- 
alence of overweight and obesity was $(22.8 \%$ and $11.8 \%$ respectively). Percent of overweighed males and females from the total participants was $(9.4 \%$ and $13.4 \%$ ) respectively. Percent of obese males and females from the total participants was $(6.6 \%$ and $5.2 \%$ ) respectively (Table 2 ). Nearly three quarters of the participants (76.4\%) had fair nutritional knowledge. On the other hand, good knowledge was found in $(19.4 \%)$ and only $(4.2 \%)$ with a poor knowledge (Table 3 ). Majority of students $(88.4 \%)$ had fairly sound nutritional behavior. On the other hand, unsound nutritional behavior was found in $(6.2 \%)$ and sound nutritional behavior in (5.4\%) of the participants (Table 4). Nearly two thirds of the participant $(66.8 \%)$ prefer healthy eating while the remaining one third (33.2\%) don't prefer healthy eating (Table 5). Regarding barriers to healthy eating, it was found that most of students' families $(59.6 \%)$ don't know how to prepare foods in a healthy way followed by $(57.2 \%)$ of the students' families don't have time to make healthy foods, $(55.4 \%)$ think that they will still hungry if they eat healthy (Table 6).

Table (1): Characteristics of the studied students $(n=500)$.

\begin{tabular}{|c|c|c|}
\hline Characteristics & No. & Percent $(\%)$ \\
\hline \multicolumn{3}{|l|}{ Study year: } \\
\hline $1^{\text {st }}$ year & 170 & 34 \\
\hline 2nd year & 170 & 34 \\
\hline 3 rd year & 160 & 32 \\
\hline \multicolumn{3}{|l|}{ Father education: } \\
\hline Illiterate & 14 & 2.8 \\
\hline Primary & 111 & 22.2 \\
\hline Secondary & 115 & 23 \\
\hline University & 260 & 52 \\
\hline \multicolumn{3}{|l|}{ Mother education: } \\
\hline Illiterate & 41 & 8.2 \\
\hline Primary & 114 & 22.8 \\
\hline Secondary & 153 & 30.6 \\
\hline University & 192 & 38.4 \\
\hline \multicolumn{3}{|l|}{ Father job: } \\
\hline Unemployed & 3 & 0.6 \\
\hline Manual worker & 79 & 15.8 \\
\hline Employee & 180 & 36 \\
\hline Professional & 109 & 21.8 \\
\hline Private work & 129 & 25.8 \\
\hline \multicolumn{3}{|l|}{ Mother job: } \\
\hline Housewife & 303 & 60.6 \\
\hline Manual worker & 1 & 0.2 \\
\hline Employee & 120 & 24 \\
\hline Professional & 43 & 8.6 \\
\hline Private work & 33 & 6.6 \\
\hline
\end{tabular}

Table (2): Prevalence of overweight and obesity among the studied group $(\mathrm{n}=500)$.

\begin{tabular}{clc}
\hline Weight grades & No. & Percent $(\%)$ \\
\hline Overweight: & 114 & 22.8 \\
Male & 47 & 9.4 \\
Female & 67 & 13.4 \\
Obese: & 59 & 11.8 \\
Male & 33 & 6.6 \\
Female & 26 & 5.2 \\
\hline
\end{tabular}

Table (3): Nutritional knowledge level among the studied group $(n=500)$.

\begin{tabular}{llc}
\hline Nutritional knowledge level & No. & Percent (\%) \\
\hline Poor & 21 & 4.2 \\
Fair & 382 & 76.4 \\
Good & 97 & 19.4 \\
\hline
\end{tabular}

Table (4): Nutritional behavior level among the studied group $(n=500)$.

\begin{tabular}{llc}
\hline Nutritional behavior level & No. & Percent (\%) \\
\hline Unsound nutritional behavior & 31 & 6.2 \\
Fairly sound nutritional behavior & 445 & 88.4 \\
Sound nutritional behavior & 27 & 5.4 \\
\hline
\end{tabular}

Table (5): Frequency of preferring healthy eating among the studied group $(n=500)$.

\begin{tabular}{lcc}
\hline $\begin{array}{l}\text { Preferring healthy eating as } \\
\text { (fruits, vegetables, meat and milk) }\end{array}$ & No. Percent (\%) \\
\hline Yes & 334 & 66.8 \\
No & 166 & 33.2 \\
\hline
\end{tabular}

Table (6): Barriers to healthy eating among those who didn't prefer healthy eating $(n=166)$.

\begin{tabular}{|c|c|c|c|c|}
\hline \multirow[b]{2}{*}{ Barriers to healthy eating } & \multicolumn{2}{|r|}{ Yes } & \multicolumn{2}{|r|}{ No } \\
\hline & No. & $\begin{array}{c}\text { Percent } \\
(\%)\end{array}$ & No. & $\begin{array}{l}\text { Percent } \\
(\%)\end{array}$ \\
\hline $\begin{array}{l}\text { - The family don't want to eat } \\
\text { healthy foods. }\end{array}$ & 80 & 48.2 & 86 & 51.8 \\
\hline $\begin{array}{l}\text { - The family don't keep healthy } \\
\text { foods in the house. }\end{array}$ & 79 & 47.6 & 87 & 52.4 \\
\hline - Healthy foods don't taste good. & 88 & 53 & 78 & 47 \\
\hline $\begin{array}{l}\text { - The family don't have time to } \\
\text { make healthy foods. }\end{array}$ & 95 & 57.2 & 71 & 42.8 \\
\hline $\begin{array}{l}\text { - Healthy foods cost too much } \\
\text { that can't be afford by family. }\end{array}$ & 88 & 53 & 78 & 47 \\
\hline $\begin{array}{l}\text { - Student will still feel hungry if } \\
\text { he/she eat healthy foods. }\end{array}$ & 92 & 55.4 & 74 & 44.6 \\
\hline $\begin{array}{l}\text { - Your family don't know how to } \\
\text { prepare foods in a healthy way. }\end{array}$ & 99 & 59.6 & 67 & 40.4 \\
\hline $\begin{array}{l}\text { - Healthy food isn't available at } \\
\text { school. }\end{array}$ & 92 & 55.4 & 74 & 44.6 \\
\hline
\end{tabular}




\section{Discussion}

The sample included 500 students, $50 \%$ of them were males and $50 \%$ were females with their age ranges from 12 to 15 years old and the mean was $13.03 \pm 0.961$. The entire sample was from urban areas: From Tanta preparatory schools. Each grade was representing nearly one third of the sample. More than half of the participants' fathers completed university education and about one third of them were employee. On the other hand, more than one third of the participants' mothers completed university education and more than half of them were housewives.

The present study showed that prevalence of overweight among students was $(22.8 \%)$ while obesity was (11.8\%). Overweighed and obese males represent (18.8\% and $13.2 \%$ respectively) from the studied males. While in females, overweight and obesity represent $(26.8 \%$ and $10.4 \%$ respectively) from the studied females. Prevalence of overweight was nearly similar with Krassas G et al., [15] in Greece who revealed that prevalence of overweight was $19 \%$ while obesity was less than our study $(2.6 \%)$. That study was carried out in Thessaloniki city (Greece) to investigate the prevalence of overweight and obesity among children and adolescents (11-17 years). The higher prevalence of obesity in our study may be due to absence of the role of governmental schools so students spend most of their day outside home and school and this force them to eat fast and unhealthy food.

Regarding prevalence of overweight, our results were higher than the results of Ogden CL et al., [16] in US. They reported prevalence of overweight (17.4\%) in their study which was carried on 1138 children and adolescents (12 to 19 years) as part of the 2003-2004 and 2005-2006 National Health and Nutrition Examination Survey (NHANES) the higher prevalence of overweight in our study may be due to absence of healthy life style for students and unavailability of healthy foods outside home.

On the other hand, Bin Zaal A et al., [17] in Dubai showed that prevalence of obesity was $20.5 \%$ and this was higher than our results. This study was carried out among adolescents aged 12 to 17 years to study dietary habits associated with obesity among adolescents in Dubai, United Arab Emirates. The main reasons for the rising levels of obesity are the improved socio-economic status of many Middle East countries, which makes life more sedentary and is coupled with diminished patterns of exercise.
Also, our results were less than El-Bayoumy I et al., [18] results in Kuwait who revealed that prevalence of overweight and obesity in adolescent Kuwaiti children aged 10 to 14 years was $30.7 \%$ and $14.6 \%$, respectively. This may be due to food consumption patterns and dietary habits in Gulf countries that have changed markedly during the past 4 decades. Kuwait has been undergoing modernization that has been shown to positively influence the level of obesity, because it is associated with physical inactivity due to increased dependence on labor-saving devices like cars, increased intake of high-caloric diet, such as soft drinks and fast foods.

Our results were in agreement with Ella NARA et al., [6] results in Egypt which showed that the overall prevalence of overweight among the age group (10-18) ranged between 19 to $23 \%$. This study was carried on seven Egyptian governorates about the prevalence of overweight and obesity among Egyptian adolescents.

Also, our results were in agreement with Talat MA and El-Shahat E [19] results in Egypt which revealed that the prevalence of overweight and obesity was ( $20 \%$ and $10.7 \%$ respectively). It was cross-sectional study which was carried out during academic year 2014-2015 to assess prevalence of overweight and obesity among preparatory school adolescents (12-15 years) in Urban Sharkia Governorate, Egypt.

However, findings of Hadhood SESA et al., [20] in Egypt regarding overweight were less than our results $(16.5 \%)$. While prevalence of obesity was higher than our study (14.6\%). This study was conducted on 711 school children between 6-14 years in Sohag, Egypt to assess prevalence and correlates of overweight and obesity among school children. These variations may be due to different residence among the studied groups where rural students in that study represented $63.2 \%$ compared with no rural students in our study. In Egypt, Sohag governorate is one of poorest governorates that results in high consumption of the cheap high carbohydrate diet and a relatively less consumptions of nutrient dense foods. In addition, availability of cars and taxies in Tanta had led to reduced physical activities of children.

Concerning nutritional knowledge level, the present study showed that nearly three quarters of the participants $76.4 \%$ had fair knowledge, followed by $19.4 \%$ with a good knowledge and only $4.2 \%$ with a poor knowledge. Our results were nearly similar to results of Ismail MA et al., [21] in Egypt 
who showed that more than half of the studied subjects $(53.5 \%)$ had got fair knowledge regarding diet needed for healthy life style. While good knowledge was reported only by $12.3 \%$ of them. The study was carried on 608 adolescents in some of preparatory schools in Ismailia city to assess knowledge, attitude and practice of adolescents towards obesity in the preparatory schools.

On the other hand, our results were dissimilar to Abd El-Rahman S et al., [1] results in Egypt who showed that more than three quarter of the studied sample had incorrect knowledge about healthy nutrition, this result was attributed to lack of knowledge they had, due to inefficiency of the implemented health education program about nutrition for this age of adolescents by health authority which either deficient or unsuitable.

Regarding nutritional behavior level, the present study showed that the majority of the students $(88.4 \%)$ had fairly sound nutritional behavior followed by $(6.2 \%)$ with unsound nutritional behavior and $(5.4 \%)$ of sound nutritional behavior. On the other hand, our results were not on the same line either with Abd El-Rahman S et al., [1] in Egypt or with Triches RM and Giugliani ERJ [22] study in Brazil about obesity, eating habits and nutritional knowledge among school children. That study was carried on 573 school children of public schools. Both studies showed that eating habits were less healthy. Abd El-Rahman S et al., [1] attributed their findings to the social level of their participants where they belonged to low and middle social class, came from rural areas, their mothers were illiterate and were house wives.

The current results were nearly similar to results of Al-Beltagy R. [23] study in Egypt about food habits among adolescents in El-Gharbia Governorate which showed that most of studied adolescents (more than 60\%) were following fairly sound dietary habits in both urban and rural areas.

The present study showed that nearly two thirds of the participants prefer healthy eating but there are some barriers to this habit in those who not prefer healthy eating. Most of their families (59.6\%) don't know how to prepare foods in a healthy way followed by $(57.2 \%)$ of the students' families don't have time to make healthy foods, $(55.4 \%)$ think that they will still hungry if they eat healthy foods and lastly (53\%) of the students think that healthy foods cost too much. It was in agreement with Croll JK et al., [24] in their study about healthy eating and what does it mean to adolescents, it was found that barriers to healthy eating include a lack of time, limited availability of healthy foods in schools, and a general lack of concern regarding following healthy eating recommendations.

On the other hand, Shepherd J et al., [25] in their systematic review about young people and healthy eating: Barriers and facilitators showed that barriers to healthy eating included poor school meal provision and personal taste preferences for fast food. Difference in barriers depends on age of the participants, family readiness to prepare healthy food with a good taste and different levels of socioeconomic status.

\section{Conclusion:}

Based on the results of the present study, we can conclude that:

1- The preparatory schools are good targets for early management of overweight and consequently obesity problems.

2- It was revealed that more than one fifth of the participants $(22.8 \%)$ were overweighed and less percent were obese (11.8\%).

3- Fair nutritional knowledge and behavior were found in most of the students.

\section{Recommendations:}

Based on the findings of the current study, the followings can be recommended:

1- Encourage healthy eating among adolescents.

2- Provide healthy snacks at school canteen with a suitable price.

3- Guide students and their families to the best YouTube channels that can help them to prepare healthy food in a rapid and delicious way.

\section{References}

1- ABD EL-RAHMAN S., ALY S.H. and EL-BASTAWESY S.: Assessment of Nutritional Status among Preparatory School Girls in Talkha City. Egyptian Journal of Hospital Medicine, 2013.

2- LISSAU I., OVERPECK M.D., RUAN W.J., DUE P., HOLSTEIN B.E. and HEDIGER M.L.: Body mass index and overweight in adolescents in 13 European countries, Israel, and the United States. Archives of pediatrics \& adolescent medicine, 2004.

3- AITSI-SELMI A., BENOVA L., SHOLKAMY H. and MARMOT M.: Addressing the double burden of malnutrition in Egypt: Do conditional cash transfers have a role? IUSSP Scientific Panel on Health Equity and Policies in the Arab World: International Seminar on Social and Health Policies for Equity: Approaches and Strategies, London, UK, 2009.

4- MUSAIGER A.O.: Overweight and obesity in eastern mediterranean region: Prevalence and possible causes. Journal of obesity, 2011. 
5- ROBERTS S.B. and DALLAL G.E.: The new childhood growth charts. Nutrition Reviews, 2001.

6- ELLA N.A.R.A., SHEHAB D.I. and ISMAIL M.A.: Prevalence of overweight and obesity, and status of chronic non-communicable diseases and some related risk factors among Egyptian adolescents. Journal of Diabetes and Endocrinology, 2011.

7- HANLEY A.J., HARRIS S.B., GITTELSOHN J., WOLEVER T.M., SAKSVIG B. and ZINMAN B.: Overweight among children and adolescents in a Native Canadian community: Prevalence and associated factors. The American Journal of Clinical Nutrition, 2000.

8- NICKLAS T.A., BARANOWSKI T., CULLEN K.W. and BERENSON G.: Eating patterns, dietary quality and obesity. Journal of the American College of Nutrition, 2001.

9- REINEHR T., KERSTING D.M., CHAHDA C., WOLLENHAUPT A. and ANDLER W.: Nutritional knowledge of obese and nonobese children. Journal of pediatric gastroenterology and nutrition, 2001.

10- PÉREZ-RODRIGO C. and ARANCETA J.: School-based nutrition education: Lessons learned and new perspectives. Public Health Nutrition, 2001.

11-MALONE H., NICHOLL H. and TRACEY C.: Awareness and minimisation of systematic bias in research. British Journal of Nursing (Mark Allen Publishing), 2014.

12- TURCONI G., GUARCELLO M., MACCARINI L., CIGNOLI F., SETTI S., BAZZANO R., et al.: Eating habits and behaviors, physical activity, nutritional and food safety knowledge and beliefs in an adolescent Italian population. Journal of the American College of Nutrition, 2008.

13- RAVINDRAN R.: Multi-level Barriers for Healthy Eating and Fruit and Vegetable Consumption among Hispanic Women Participating in a Healthy Eating Intervention: Findings from the Nuestras Comidas Project: University of Washington, 2014

14- CHARTS E.G.: Cairo University, Diabetic Endocrine and Metabolic Pediatric Unit and the National Research CenterCairo, in collaboration with Wright State University, 2002.
15- KRASSAS G., TZOTZAS T., TSAMETIS C. and KONSTANTINIDIS T.: Prevalence and trends in overweight and obesity among children and adolescents in Thessaloniki, Greece. Journal of pediatric endocrinology \& metabolism: JPEM, 2001.

16- OGDEN C.L., CARROLL M.D. and FLEGAL K.M.: High body mass index for age among US children and adolescents, 2003-2006. J.A.M.A, 2008.

17- BIN ZAAL A., MUSAIGER A. and D'SOUZA R.: Dietary habits associated with obesity among adolescents in Dubai, United Arab Emirates. Nutricion Hospitalaria, 2009.

18-EL-BAYOUMY I., SHADY I. and LOTFY H.: Prevalence of obesity among adolescents (10 to 14 years) in Kuwait Asia Pacific Journal of Public Health, 2009.

19- TALAT M.A. and EL-SHAHAT E.: Prevalence of overweight and obesity among preparatory school adolescents in Urban Sharkia Governorate, Egypt. Egyptian Pediatric Association Gazette, 2016.

20- HADHOOD S.E.S.A., ALI R.A.E., MOHAMED M.M. and MOHAMMED E.S.: Prevalence and correlates of overweight and obesity among school children in Sohag, Egypt. Open Journal of Gastroenterology, 2017.

21- ISMAIL M.A., KAMEL M.H. and IBRAHIM D.E.: Assessment of knowledge, attitude and practice of adolescents towards obesity in the preparatory schools in Ismailia city-Egypt. Egyptian Journal of Community Medicine, 2011.

22- TRICHES R.M. and GIUGLIANI E.R.J.: Obesity, eating habits and nutritional knowledge among school children. Revista de saúde pública, 2005.

23- AL-BELTAGY R.: Food Habits among Adolescents in El Gharbia Governorate. Nutrition and Food Science Department, Faculty of Home Economics, Al-Azhar University, 2008.

24- CROLL J.K., NEUMARK-SZTAINER D. and STORY M.: Healthy eating: What does it mean to adolescents? Journal of nutrition education, 2001.

25- SHEPHERD J., HARDEN A., REES R., BRUNTON G., GARCIA J., OLIVER S., et al.: Young people and healthy eating: A systematic review of research on barriers and facilitators. Health Education Research, 2006. 


\section{مشكلة الوزن الزائد في مرحلة المراهقة المبكرة

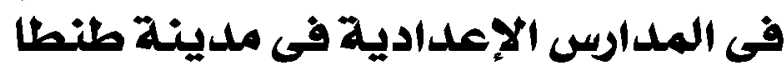

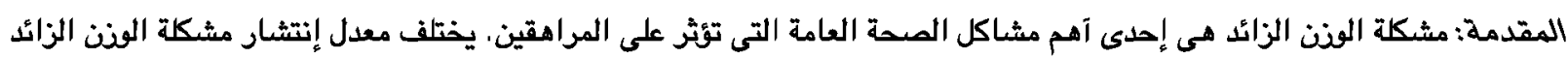

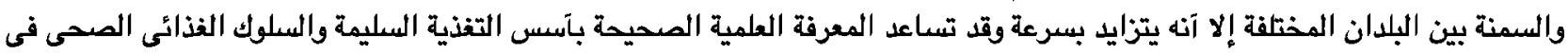
الوقاية من الوذن الزائد والسمنة.

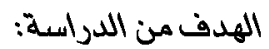

ا- تقييم إنتشار مشكلة المذن الزائد والسمنة بين آطفال المدارس الإعدادية فى مدينة طنطا.



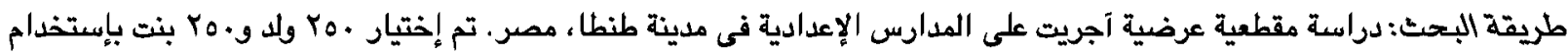

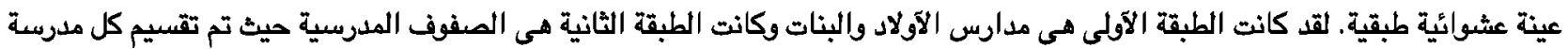

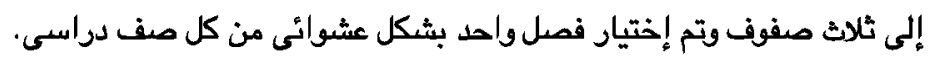

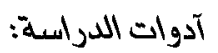

ا- إستبيان يتكون من (الييانات الإجتماعية الديموغرافية، آسئلة حل المعرفة والسلوك التغدهى). r- قياس الطول والوذن لحساب مؤشر كتلة الجسم.



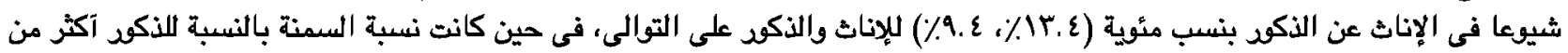

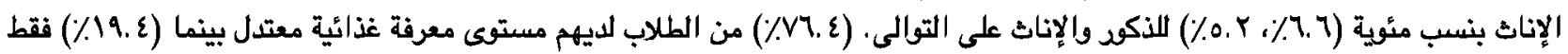

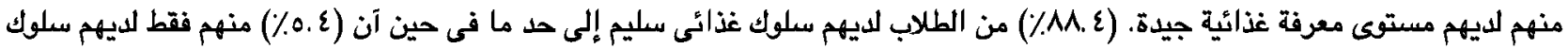
غذائى سليم'

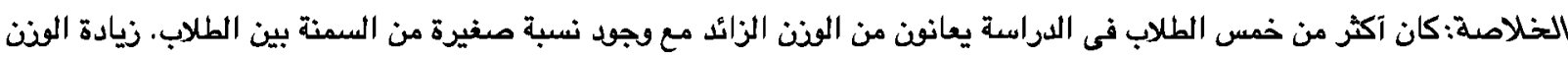

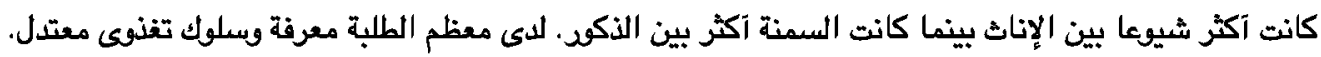

ا - تشجيع المراهقين على الآكل الصحى.

Y- تقديم وجبات خفيفة صحية فى مقصف المدرسة بسعر مناسب. ب- توجيه الطلاب وعائلاتهم إلى آفضل قنوات اليوتيوي التى يمكن آن تساعدهم فى إعداد الطعام الصحى بطريقة سريعة ولذيذة. 